\title{
Reforming the Shareholder's Derivative Suit in Nigeria: Perspectives from the United States
}

\author{
Dr Gogo G. Otuturu, LL.B, LL.M, PhD, B.L, ACIArb (Nigeria), \\ Solicitor and Advocate of the Supreme Court of Nigeria; Lecturer, Faculty of Law, Niger Delta University, \\ Wilberforce Island, Bayelsa State, Nigeria \\ Dr Ayebaesin J Beredugo, LL.B, LL.M, B.L, LL.D (Pretoria), \\ Solicitor and Advocate of the Supreme Court of Nigeria; Lecturer, Faculty of Law, Niger Delta University, \\ Wilberforce Island, Bayelsa State, Nigeria.
}

\begin{abstract}
The shareholder's derivative suit was developed by courts of equity as an exception to the majority rule. It provides opportunity for a minority shareholder to bring an action in the name and on behalf of the company to redress wrongs done to the company by directors who are in control. This paper examines the shareholder's derivative suit in Nigeria under the Companies and Allied Matters Act 1990. It highlights the procedural obstacles and financial burdens on the shareholder and suggests that the requirement of notice on the directors should be excused in cases of fraud and illegal transactions by the directors. It also suggests that, a derivative action being a corporate action initiated by the shareholder in the name of the company and on its behalf, the company should be made to bear not only reasonable legal fees but also all the expenses connected with the proceedings.
\end{abstract}

Keywords: derivative suit, majority rule, management control, minority rights

DOI: $10.7176 / \mathrm{JLPG} / 94-12$

Publication date: February $29^{\text {th }} 2020$

\section{Introduction}

It is a general principle of corporate law that directors owe their duties to their company, not the shareholders who own the company. Accordingly, the proper plaintiff in an action to remedy breach of duty by directors is the company itself. An individual shareholder or a minority of shareholders cannot bring an action in court to redress any wrongs or irregularities committed by the directors in the conduct of the business of the company.

In Edwards v. Halliwell Jenkins LJ contended that the will of the majority, vis-à-vis the minority, is to be identified with that of the company. Consequently, to say that the company is prima facie the proper plaintiff in actions concerning its affairs is only another way of saying that the majority, within the limits of their power to ratify, have the sole right to determine whether or not a dispute shall be brought before the courts. This is what is generally known as the "majority rule."

This paper examines the shareholder's derivative suit under the Companies and Allied Matters Act 1990. In particular, it examines the development of shareholder's remedies by way of exceptions to the majority rule and the forms of shareholder's action. It also examines the procedural requirements of the shareholder's derivative suit in other jurisdictions and offers suggestions for reform of the shareholder's derivative suit in Nigeria.

\section{Development of Shareholder's Remedies}

The majority rule was formulated in the famous English case of Foss v. Harbottle ${ }^{2}$ where two minority shareholders challenged the sale by directors of their own property to the company at an inflated value. It was held that the proper plaintiff in an action in respect of a wrong alleged to have been done to the company is prima facie the company itself and that an internal irregularity in the conduct of the board of directors will not be actionable if ratified by majority of the shareholders.

The term "majority" was not defined in Foss $v$. Harbottle itself or the line of cases following it. However, "majority" has been defined in relation to a shareholder as one who owns or controls more than fifty percent of the shares of a company. ${ }^{3}$ This is obvious in the case of private companies or close corporations with two or three shareholders. If one of them owns or controls more than half of the shares, then he is definitely a majority shareholder.

However, the emphasis is on control and effective control could be maintained with less than fifty percent of the shares especially in public companies with wide shareholding. In such a case, majority means shareholders who have command of the majority of the votes, or directors who are in control of the affairs of the company.

(1950) 2 All E.R. 1064 at p.1066

(1843) 58 E.R. 189. See generally Tom Hadden, Company Law and Capitalism (London: HFL Publishers Ltd., 1981) 271

CH Black, Black's Law Dictionary $\left(6^{\text {th }}\right.$ edn, West Publishing Co 1990) 55 
Thus majority is not to be understood in terms of the number of shareholders but in terms of control exercised by shareholders at meetings of the company (that is, voting control) or control exercised by directors over the management of the affairs of a company (that is, management control). In Edwards v. Halliwell (supra) Jenkins LJ stated the import of the majority rule thus:

The rule in Foss v. Harbottle, as I understand it, comes to no more than this. First, the proper plaintiff in an action in respect of a wrong alleged to be done to a company or association of persons is prima facie the company or association itself. Secondly, where the alleged wrong is a transaction which might be made binding on the company or association and on all its members by a simple majority of the members, no individual member of the company is allowed to maintain an action in respect of that matter for the simple reason that, if a mere majority of the members of the company or association is in favour of what has been done, then cadit questio. No wrong has been done to the company or association and there is nothing in respect of which anyone can sue. ${ }^{4}$

It is clear that there are two branches of the rule and these have been described as the proper plaintiff principle and the internal management principle. The internal management principle was further explained in MacDougall v. Gardiner ${ }^{5}$ where Mellish LJ said:

In my opinion, if the thing complained of is a thing which in substance the majority of the company are entitled to do, or if something has been done irregularly which the majority of the company are entitled to do regularly, or if something has been done illegally which the majority of the company are entitled to do legally, there can be no use in having litigation about it, the ultimate end of which is only that a meeting has to be called, and then ultimately the majority gets its wishes.

The justification for the rule is two-fold. The first is the need to preserve the right of the majority to decide how the company's affairs shall be conducted. The second is the avoidance of multiplicity of futile suits, which will cause the company grave embarrassment and financial loss. Thus in Gray v. Lewis ${ }^{6}$ James LJ justified the principle that any "body corporate" is the proper plaintiff in proceedings to recover its property, by pointing to the obvious danger of a multiplicity of shareholders' suits in the absence of a rule such as Foss v. Harbottle. According to him, 'There might be as many bills as there are shareholders multiplied into the number of defendants.' 1

However, strict adherence to the rule may be a shield for directors who themselves may be the wrongdoers, so that injustice caused by their acts may never be redressed. This fact was recognized even in Foss v. Harbottle itself when Wigram VC said:

If a case should arise of injury to a corporation by some of its members, for which no adequate remedy remained, except that of a suit by individual corporators in their private characters, and asking in such character the protection of those rights to which in their corporate character they were entitled, I cannot but think that... the claims of justice would be found superior to any difficulties arising out of technical rules respecting the mode in which corporations are required to sue. ${ }^{7}$

Both under the general law and the Companies Acts of the various jurisdictions, there is some protection of the minority of members against the acts of the majority. As Palmer points out:

A proper balance of the rights of majority and minority shareholders is essential for the smooth functioning of the company... The Companies Acts ... and the relevant case law, attempt to maintain that balance by admitting, on principle, the rule of the majority but limiting it, at the same time, by a number of well-defined minority rights. ${ }^{8}$

What the learned jurist calls "minority rights" can properly be described as shareholders' remedies or more aptly as "exceptions" to the majority rule. They are popularly described as exceptions in that they represent classes of cases which may not be ratified by the majority, and which may be redressed by personal shareholder action or derivative suit.

Through the cases, four main exceptions to the rule can be restated. The first exception applies to acts, which are ultra vires or illegal. The second exception is concerned with the violation of special procedures. The third exception relates to the invasion of personal rights. The fourth exception is that a shareholder may bring a derivative action to prevent controlling shareholders or directors from perpetrating a fraud on the minority.

The Companies and Allied Matters Act 1990 has codified both the majority rule and its exceptions under English law. The Act provides as follows:

Edwards (n1) 1066

(1875) 1 Ch.D 13 at p. 25

(1873) 8 Ch. App. 1035

Ibid 1051.

Foss v. Harbottle (supra) at p. 203

Clive M Schmithhoff (Ch. 2) 597 
Subject to the provisions of this Act, where irregularity has been committed in the course of a company's affairs or any wrong has been done to the company, only the company can sue to remedy that wrong and only the company can ratify the irregular conduct. ${ }^{9}$

The rule in Foss v. Harbottle was explained and applied by the Supreme Court in Adenuga \& Ors v. Odumeru \& $O r s^{10}$ where Uwaifo JSC said:

The rule in Foss v. Harbottle is simply that when a decision has been irregularly taken on behalf of a company, it will be futile for the minority shareholders to take legal steps to oppose it since, if it is a decision the company or corporation can take, the majority shareholders can easily ratify it. That is a rule which in that case has resulted from the refusal of the court to interfere in the management of a company at the instance of a minority of members who were dissatisfied with the conduct of the company's affairs by the majority or by the board of directors on the basis that it is a waste of time to seek to get the court to set aside what may be ratified by a majority of members once it is within their power to do so... The rule is now given statutory effect under section 299 of the Companies and Allied Matters Act, 1990. There are, of course, known exceptions now also provided in section $300 .{ }^{11}$

\section{Forms of Shareholder's Action in Nigeria}

There are three different forms of action open to minority shareholders in Nigeria under the Companies and Allied Matters Act 1990. These are personal action, representative action and derivative action. It would be necessary to consider the requirements and incidents of each of these forms of minority shareholder's action.

\section{Personal Action:}

A shareholder may institute a personal action against the company to enforce a right due to him personally. Such a right may originate from the articles of association, or from a separate contract between the shareholder and the company, or from some special duty owed to the shareholders by the directors. ${ }^{12}$

In any case, a shareholder suing in his personal capacity shall not be entitled to damages but only to declaration or injunction to restrain the company or the directors from doing a particular act. However, the court may award cost to him whether or not his action succeeds. ${ }^{13}$

\section{Representative Action:}

A representative action is open to any minority shareholder suing on behalf of himself and some other shareholders who share an interest with him in the proceedings. This form of action prevents multiplicity of personal actions by various minority shareholders with a common interest and a common grievance.

It follows that there must be a common interest and a common grievance and also the relief sought is in its nature beneficial to all whom the plaintiff proposes to represent. A typical example of a representative action is the case of Tika-Tore Press Ltd. v. Abina ${ }^{14}$ where the plaintiffs sued for themselves and on behalf of other members of Tika-Tore Press Limited.

Here too the applicant is not entitled to damages but only to declaration or injunction. However, the court has discretion to award costs to him as it thinks fit, whether or not he succeeds in the action. ${ }^{15}$ This is obviously a codification of the decision in Wallersteiner v. Moir. ${ }^{16}$

\section{Derivative Action:}

A minority shareholder may be permitted by the court to institute a derivative action in the name or on behalf of the company to enforce a corporate right in circumstances where the alleged wrongdoers control the company. In other words, such actions derive from the need to permit minority shareholders to stand in for the company and enforce certain rights belonging to it. Such derivative actions are governed by special procedural rules, which do not apply to other shareholders' actions, whether in the personal or representative form.

Before a derivative action is commenced, a minority shareholder must first obtain a court order permitting him to commence the action. In practice, this is done is by motion ex parte supported by an affidavit stating the facts in support of the motion Before granting this order, the court must be satisfied that the following conditions have been met:

\section{CAMA, s. 299}

(2003) 8 NWLR (Pt. 821) 163

Ibid 183-184. See also Solomon Tanimola \& Ors v. Surveys and Mapping Goedata Ltd \& Ors (1995) 6 NWLR (pt. 403) 617; SPDC \& Ors v. Nwaka (2003) 6 NWLR (Pt. 815) 184.

GA Olawoyin, Status and Duties of Company Directors (Ile-Ife: University of Ife Press, 1977) 279.

CAMA, s. 301.

(1973) NMLR 220

CAMA, s. 301.

(No. 2) (1975) 1 All E. R. 849 
the alleged wrongdoers must be the directors who are in control and so will not take necessary action;

(b) the applicant must give reasonable notice to the directors of his intention to apply to the court if they do not take necessary action;

(c) the applicant must act in good faith and must not himself be a party to the wrong which is the subject of the dispute; and

(d) the action must be in the best interest of the company. ${ }^{17}$

In American law, an increasingly liberal interpretation of the rule controlling the shareholders' right to bring a derivative action has led to serious abuses. These abuses have resulted in legislative intervention to check what are termed "strike suits." 18 Legislations to counteract these tendencies have taken the form of "security for expenses" statutes. ${ }^{19}$

Under the Companies and Allied Matters Act, the court has wide discretionary powers to make such order or orders as it may think fit, including one or more of the following:

(a) authorizing the applicant or any other person to control the conduct of the action;

(b) giving directions for the conduct of the action;

(c) directing that any amount adjudged payable by the defendant in the action shall be paid directly to former and present shareholders of the company instead of the company; and requiring the company to pay reasonable legal fees incurred by the applicant in connection with the proceedings. ${ }^{22}$

\section{Perspectives from the United States}

In the United States of America, shareholder's derivative suit involves the assertion by a shareholder of a corporate cause of action against persons either in or out of the corporation who have allegedly wronged it. Such suits are brought where the corporation has failed to enforce such claims. Some examples of derivative suits are suits:

(a) To recover damages resulting from an ultra vires act;

(b) To restrain corporate officers from breaching their fiduciary duty to the corporation;

(c) To recover improperly paid dividends;

(d) To restrain outsiders from committing a wrong to the corporation or to recover from such wrong. ${ }^{23}$

In some jurisdictions, certain procedural requirements must be met in a shareholder's derivative suit. Firstly, there must be a "demand" upon the board of directors to take proceedings on behalf of the corporation. Secondly, there must be another similar "demand" addressed to the general body of shareholders. ${ }^{24}$

In each case, the minority shareholder must aver in his pleadings that he has made these demands, one or both of which have been wrongfully refused. Alternatively, he must aver that it would be futile in the circumstances to make one or both of these demands and that the law therefore excuses him.

The law varies as between different jurisdictions as to what circumstances may excuse a "demand" or render its refusal wrongful in order to allow a minority shareholders' action. By far, the most commonly accepted excuse is that a majority of the directors are the alleged wrongdoers. The courts have unanimously held that in such a case, the demand is futile since it is unreasonable to expect that a man will vote to bring a suit against himself. ${ }^{25}$ The same reasoning would apply when majority of the directors are under the control of the wrongdoers and would not reasonably be expected to vote for acceptance of the demand. ${ }^{26}$

For the same reason as in the case of demand on directors, demand on shareholders would always be excused

17 CAMA, s. 303

18 These are blackmailing actions brought with a view to personal gain by shareholders with a minimal stake in the corporation and even less interest in its welfare.

19 These statutes usually require that the plaintiffs, unless they possess certain proportion of the corporation's shares, must provide security for the corporation's litigation expenses.

22 CAMA, s 304. Under the Ghana Companies Code 1963, a shareholder has the same right to institute proceedings on a corporate cause of action as does the board of directors or the shareholders in general meeting. However, on the application of any defendant, the court may stay such proceedings if it is satisfied that in all circumstances, including his participation in the transaction complained of and the circumstances in which he became a member, it is inequitable that the shareholder should be allowed to have the conduct of the action. See the Ghana Companies Code 1963, s 210(6). One area of similarity with the American law is that the Ghana Companies Code gives the court power to order the plaintiff to "give security for the payment of the costs of the defendants." The Companies and Allied Matters Act 1990, on the other hand, gives the court power to determine whether or not to permit a minority shareholder to sue except that it shall not require the plaintiff to give security for costs. See CAMA, s 307.

23 Dodge v. Woolsey, 18 How. (59 UD) 331 (1855) where the United States Supreme Court upheld a shareholder's derivative suit against an outsider to restrain the collection of illegal tax, payment of which would be a waste of corporate assets but the corporation refused to take action.

24 See, for example, Wolgin v. Simon, 722 F. 2 d 389 ( $8^{\text {th }}$ Cir. 1983); Zimmerman v. Bell, 585 F. Supp. 512 (D. Md. 1984). The Model Business Corporation Act 1985 Revision, s. 7.40 and most state statutes following it do not contain this requirement.

25 Reed v Hollingsworth, 157 Iowa 94, 135 N.W. 37 (1912); Von Arnim v American Tube Works, 188 Mass. 516,74 N.E. 680 (1905).

$26 \quad$ Bartlet v New York N.H. \& H.R.R., 122 Mass. 530, 537, 109 N. E. 452, 455 (1915) 
when the wrongdoers own majority of the shares or when the wrongdoers control majority of the shares. In the leading case of Delaware \& Hudson Co. v. Albany \& S.R.R $R^{27}$ the plaintiffs alleged that the defendants controlled a majority of the shares, though they owned only 8,840 out of 35,000 and the plaintiffs themselves held 8,000 . Nevertheless, the Supreme Court held that a demand was unnecessary.

Perhaps the most frequently recognized excuse for failure to make a demand on shareholders is that they have no power to ratify the wrong complained of. ${ }^{28}$ In the celebrated case of Mayer $v$. Adams (supra) the plaintiff shareholder brought an action to redress alleged frauds and wrongs committed by the defendants upon the corporation. The amended complaint set forth reasons why demand on the directors for action would be futile. It also set forth reasons seeking to excuse failure to demand stockholder action. The Vice Chancellor was of opinion that, notwithstanding these allegations, demand on stockholders would not necessarily have been futile. He accordingly dismissed the complaint. The plaintiff appealed. The Supreme Court of Delaware narrowed the issue between the parties to this: If the ground of the derivative suit is fraud, is demand for stockholder action necessary under the rule? The court answered in the negative. Southerland CJ said:

We hold that if a minority stockholder's complaint is based upon an alleged wrong committed by the directors against the corporation, of such a nature as to be beyond ratification by a majority of the stockholders, it is not necessary to allege or prove an effort to obtain action by the stockholders to redress the wrong. The question may be asked: In what circumstances is such demand necessary? Obviously the rule contemplates that in some cases a demand is necessary; otherwise, it would have not been adopted. We are not called upon in this case to attempt to enumerate the various circumstances in which demand on stockholders is excused; and likewise we do not undertake to enumerate all the cases in which demand is necessary. It seems clear that one instance of necessary demand is a case involving only an irregularity or lack of authority in directorate action. ${ }^{29}$

Similarly, in Brewer v. Boston Theatre ${ }^{30}$ the Massachusetts Supreme Court stated that where fraudulent conduct or ultra vires acts are the ground of complaint, both forms of demand are excused. Thus, minority shareholders' actions for acts ultra vires the company and for fraudulent oppression of the minority were permitted as unquestioned exceptions to the rule.

Another important aspect of the shareholder's derivative suit in the United States is what has been described as the "double derivative" suit. The double derivative suit allows an action by minority shareholders in a parent company for any injury to a subsidiary company where the wrongdoers also control the parent company. ${ }^{31}$

\section{Suggestions for Reform}

The requirement that the applicant must give reasonable notice to the directors of his intention to apply to the court if they do not take necessary action ${ }^{32}$ is clearly a borrowing from the American requirement of demand on the board of directors and should be excused in cases of fraud and illegal transactions by the directors, which could not be ratified by the company in general meeting. This will reduce the time and the expenses connected with the proceedings.

It is not enough for the court simply to require the company to pay reasonable legal fees incurred by the applicant or to pay interim costs to him during the proceedings. ${ }^{33}$ Being a corporate action, and the applicant having been permitted by the court to bring the action in the name of the company and on its behalf, the company should be made to bear all the expenses and legal fees connected with such proceedings.

The applicant in a derivative suit should be allowed to join outsiders who have collaborated with the directors who are the wrongdoers, to restrain them from committing a wrong to the company or to recover from such wrong. This will enable the company to recover corporate funds or property in the hands of a third party.

In these days of increasingly complex corporate structures, there is need for some equivalent of the "double derivative" suit. Finally, subject to judicial discretion, the shareholder's derivative suit should be extended to give minority shareholders some right to intervene in and take over proceedings against the company which are not being satisfactorily defended.

213 U.S. 435 (1909)

Meyerv Adams, 141 A.2d 458 (Del. 1958); Fisher v National Mortgage Loan Co., 132 Neb. 185, 271 N.W. 433 (1937); Continental Sec. Co. $v$ Belmont, 206 N.Y. 7, 99 N.E. (1912).

9 Quoted in Robert W Hamilton, Cases and Materials on Corporations including Partnerships and Limited Partnerships ( ${ }^{\text {rd }}$ edition, Minnesota: West Publishing Co 1986) 1095.

104 Mass. $374(1870)$

1 For further details, see Painter, 'Double Derivative Suits and Other Remedies with Regard to Damaged Subsidiaries' (1961) 36 Indiana L.J. 143.

2 CAMA, s. 303

33 Ibid, s 304. 


\section{Conclusion}

The shareholder's derivative suit was developed by courts of equity as an exception to the rule in Foss $v$. Harbottle $^{34}$ It provides opportunity for a minority shareholder to bring an action in the name and on behalf of the company to redress wrongs done to the company by directors who are in control. The Companies and Allied Matters Act 1990 has codified the rule in Foss v. Harbottle and the exceptions to it. It has also provided a statutory procedure for the shareholder's derivative suit.

However, there is still much to learn from the developments in the United States. The circumstances when the courts will excuse a demand on the directors, actions by minority shareholders to restrain outsiders from committing a wrong to the company or to recover from such wrong, and the double derivative suit which allows action by minority shareholders in a parent company for any injury to a subsidiary company are developments in the United States, which should form the agenda for further reform of the shareholder's derivative suit in Nigeria.

34. Harbottle (n 2) 